\title{
Spanish fortifications in Asia: a case study of Intramuros district in Manila - current situation and future prospects
}

\author{
J. R. Jiménez Verdejo ${ }^{1}$, J. M. Cabeza-Lainez ${ }^{2}$, J. A. Pulido-Arcas ${ }^{2}$ \\ \& C. Rubio-Bellido ${ }^{2}$ \\ ${ }^{1}$ University of Shiga Prefecture, Japan \\ ${ }^{2}$ University of Seville, Spain
}

\begin{abstract}
This paper analyses the morphological characteristics and the historical evolution of the Spanish fortification in the city of Manila, which is known as Intramuros. In turn, an analysis for future prospections, which leads to its revalorization, is also produced. This case study constitutes a unique example of the Spanish expansion in Asia, with strong ties to other cultures present in this territory. After the establishment of Manila as the capital city of the first Spanish colony in Asia in 1571, the construction of the permanent fortification system was approved, following the designs that the Ordinances of Phillipe II established for the Spanish settlements in the New World. This part of Manila has been the epicenter of the historical affairs that affected the whole country since the 16th century. In turn, this historical background has left a strong footprint in this fortification system as well as in its inner grid city, which, in fact, has been partially destroyed and rebuilt several times. Our study focuses on the actual condition of the fortification system in relation to its original conception and historical evolution; it was accomplished through a field study of the Intramuros district in Manila conducted in 2010, together with an analysis of available historical cartography and historical records. This up-to-date situation of the fortification leads to a proper understanding of its morphological evolution in relation to historical events, and also establishes a frame to understand the hints for its preservation and revalorization for the future. Keywords: Philippines, Manila, Spanish fortifications, colonial cities.
\end{abstract}




\section{Introduction}

This paper contains the essential information derived from a research project entitled "Survey and research on the origin, transformation and conservation of the colonial urban space", which extends and deepens the objectives of the present paper, and which took place from 2010 to 2012. The process of accomplishment of the main research was approached through the study of the files stored in the General Archive of the Indias (Archivo General de Indias AGI); in Seville, where all the files of relevance were consulted (152 microfilms); in Madrid, the General Archive of the Army (Servicio Histórico Militar SHM) and the General Geographical Service of the Army (Servicio geográfico del ejército SGE), where all the materials related to maps were consulted (1514 sheets and 10 volumes).

The paper focus in the nucleus of the capital city of The Philippines, Manila, which is called Intramuros. The formation of the city has been understood through a detailed study of historical maps, and also an on-site investigation, in order to clarify the current situation of the element of study; the general guidelines of the street system and the block configuration have been taken into account. The comparison with other Spanish Colonial cities, such as Cebú and Vigan can help building a stronger point of view in terms of understanding the process of Spanish colonialism in Asia.

Manila was, following Cebú and Panay, the third colonial city founded and built by Miguel López de Legazpi. Intramuros (inner city inside the walls) takes this name from the fact that the whole area is surrounded by a fortification.

Main references that have been consulted are quoted in the following paragraph, but we have to point out that here are not many previous researches on Manila. From the general point we can quote about the research about Spanish colonial cities in The Philippines carried out by Reed [1]; his $\mathrm{PhD}$ thesis makes a shallow glance about Intramuros district. Apart from this we can quote Galván Guijo [2] and Ortiz Armengol [3], both of which provide material that connects the formation of the various Spanish colonial cities. Torres [4] makes a profound study about the formation of the buildings in the inner Intramuros. Apart from this contemporary material, the Vice-governor of The Philippines from 1595 to 1603, de Morga [5], wrote a book called "Sucesos de las Islas Filipinas", from which valuable information has been extracted.

On site data was acquired through a field research from 11th September 2009 to 24th September 2009 by Shuji Funo, Juan Ramón Jimenez Verdejo and Iida Toshifumi. Wakamatsu Kentaro, Jimenez Verdejo, Tetsuda Shiota, and Kenta Yamada dis also field surveys from 31st July 2010 to 13rd August 2010, and Jimenez Verdejo, Umetani Keizo and Pyeongtaek from 2nd November 2011 to 9th November 2011.

\section{Materials and maps of Manila and Intramuros}

Relevant materials and maps about the Spanish colonial cities in The Philippines are located in 299 files in the Archivo General de Indias (AGI) in Seville, 105 of which are related to Manila. In Madrid, the materials can be found at the Servicio 
General del Ejército and Servicio Histórico Militar (SGE/SHM) in 149 files, 43 of which are related to Manila. Apart from this, although the author of these materials is unknown, we can find in Jose Luis Bello fine arts museum materials about Manila from 1640 to 1650 , in the city of Puebla (México); city views from the period 1715-1720 can be found in The Simancas Archives of Valladolid (AGS) from Antonio Fernández Rojas; also, documents about the city planning period from 1729 to 1739 from Valdés Tamón (1738) have to be taken into account; and last, documents about the city planning from the American governance period from Daniel Hudson Burham.

Considering several types of city models seen in Spanish colonial city maps, we can distinguish: A, general map; B, military map; C, area planning maps; D, city general view; E, city planning map; F, architectural plan view; G; detailed view of architectural elements in the city.

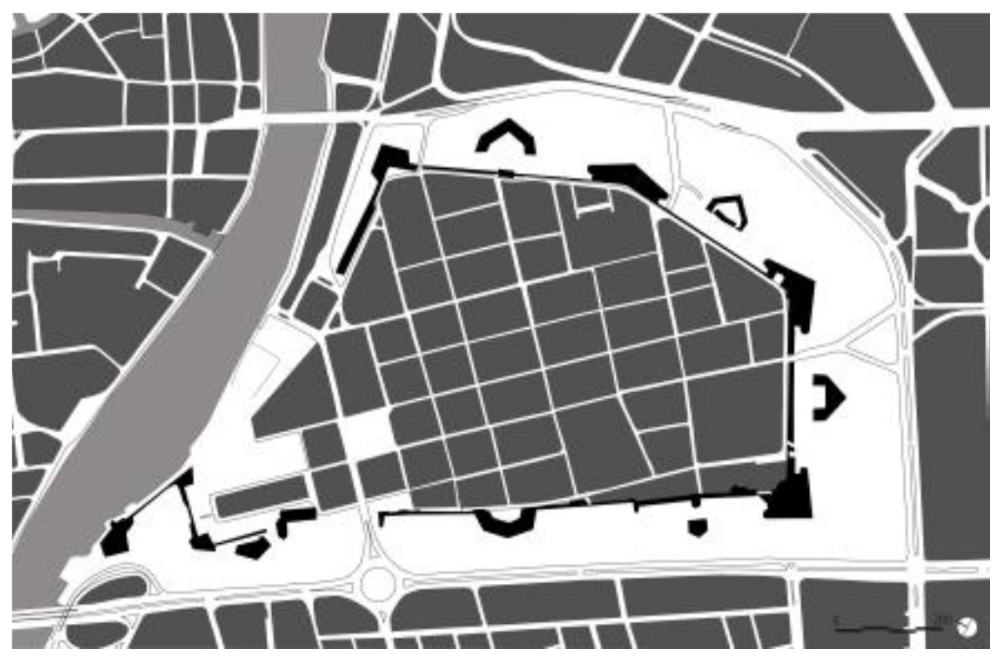

Figure 1: Contemporary spatial configuration of Intramuros District. (Own production.)

Amongst these materials we can find many materials about the fortress of Intramuros in Manila city: in F, architectural city planning, F-1 material about architectural city planning (church, various facilities, housing, etc), F-2 map (fortress, city walls, city gates, towers, etc), can be seen. Also this is related with several maps about Manila; material D contains several materials (contained in 42 sheets) material E contains material about the city planning (contained in 6 sheets), F-1 contains materials about maps about various architectural drawings (contained in 39 sheets), F-2 contains maps, about fortress (contained in 66 sheets).

The sum of several views of D (many city views) and E (city planning maps) are contained in 48 sheets. The city view was drawn, but only the city block configuration inside Intramuros. City views about the surroundings of Intramuros and also the city blocks. Intramuros is not drawn, or only partially, but the surrounding towns are drawn. 


\section{The process of architecture in Intramuros}

The presented result is based on the study and elaboration of various documents, such as materials and maps, focusing on the age of the building inside Intramuros, and summarised in the transformation and contraction process of Intramuros. Further, are shown maps of the main stage, corresponding to figs $2-6$ below, and also shows the GIS map data structure for Intramuros.

A. Intramuros in Manila is physically located in the triangular bank formed by the sediments deposited by the Pasig River and the Bay Lake into what is called the Manila Bay. It was inhabited approximately in the 10th Century by the Barangay (as expressed in Tagalo), which were farmers and hunters, and also established commercial trade with Asia. From the 13th Century to the 16th Century, Manila was unified by the chief of Kings called Raj a Rajahs, or Lacan Lakan, governing in the South bank of the Passig River estuary. In the North bank, Lakan Doula Lakan governed a group called Tondo, which prospered as a port city.

B. In 1571 a tree trunk is buried, as the tradition establish, to locate the central plaza, called Plaza Mayor; that is, ceremony of foundation has taken place. The main institutions were established: The Government House (Palacio Real o Casas del Cabildo), the Manila Cathedral, located in the West side to the south of the Plaza Mayor. Initially, the Government House was established in the fort of the Soliman period, but was moved to this area after the 1645 earthquake.

C. Manila was initially protected by a wooden fence. In response to the attack perpetrated by the Chinese pirate Ling Feng in 1574, Guido de Cabezares planned a wooden fence around Manila. This enclosure was completed in the period of the next governor, Francisco de Sandes (1575-1580), and also a watch tower, called de los Caballeros was built. Governor Gonzalo Ronquillo de Peñalosa (1580-1583) founded the Chinese Parian in 1582. After the death of Ronquillo in 1583, during the celebration of his funeral in San Agustín Church fire broke out and burned down the city.

D. In response to the mayor fire in Manila, governor Santiago de Vera (15841590), ordered the reconstruction of the city in Stone. The oldest dated building of stone was the Santiago Church by the Jesuit Antonio Sedeño. The fortress of Nuestra Señora de Guía was also built in the seashore. The fort made of wood that was in the Passig River is made of Stone, and was given the name Fort Santiago in the period (1589-1592). The next governor Gómez Pérez Dasmariñas (1590-1593) and his son Luis Pérez Dasmariñas (15931596) continued the reconstruction of the former wooden wall in stone, following the plans that Leonardo did for Torino. Nuestra Señora de Guía Fortress is also rebuild under the name of San Diego Fortress [6].

E. Citadel of Manila is completed in 1603, and plans to build a moat that surrounds the walls began in 1603. At the same time, San Andrés fortress (Baluarte de San Andrés, 1603), Parian fortress Revellín del Parián (1603), Baluarte de Santa Isabel (1609-1632) were built, strengthening in this way 
the defensive character of the city. In 1611, the University of Santo Tomás, the oldest University in Asia, was built in 1611. Over the Passig River Puente de España (Spain's Bridge, 1623) is built, and at the same time, the main bridge and also main gate of the Citadel (Puente principal) is completed. Completion of Intramuros can be confirmed through the view of the city in 1671 ; by this time, 54 blocks and 5 gates were placed in the walls.

F. In 1718 the construction of the moat of Fort Santiago begins, as an independent structure. In 1757, works on the protection of the banking the Passig River are started, and the reclamation of the coastline in the northern Tondo district begins. Furthermore, in 1754 an octagonal market is built in the Parian, which is the Real Alcaicería de San Fernando. Starting in 1756, the Seven's Years war broke up between Frande, the United Kingdom and also involving the Spanish Empire. The Philippines, and also Manila, were occupied by British forces; the war ended in 1763 with the treaty of Paris, by which Manila and The Philippines were returned to Spain; as a consequence, urban renewal plans for Manila were devised in order to strengthen its military character.

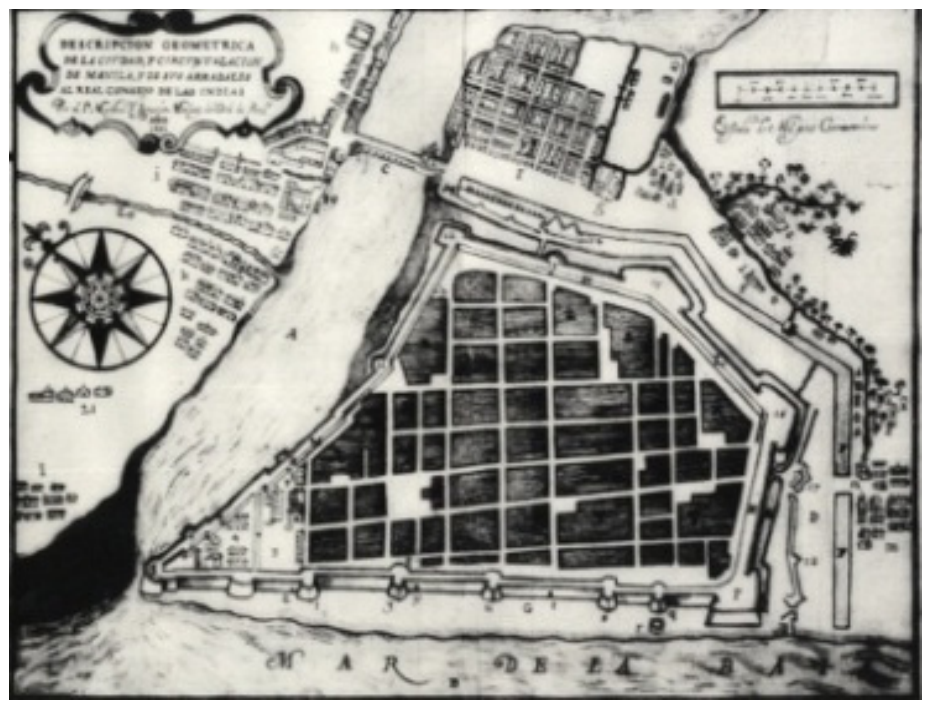

Figure 2: $\quad$ AGI, MP-Filipinas, 1671.

From the graphical documents we can assure that from 1671 little changes can be observed in the block configuration in inner Intramuros; also, the Chinese market in the Parian are and La Alcaicería de San José are built in an urban area that is changed. From the view of 1770 we can quote the expansion of open spaces; the city view painted in 1783 shows the residential land structure. 


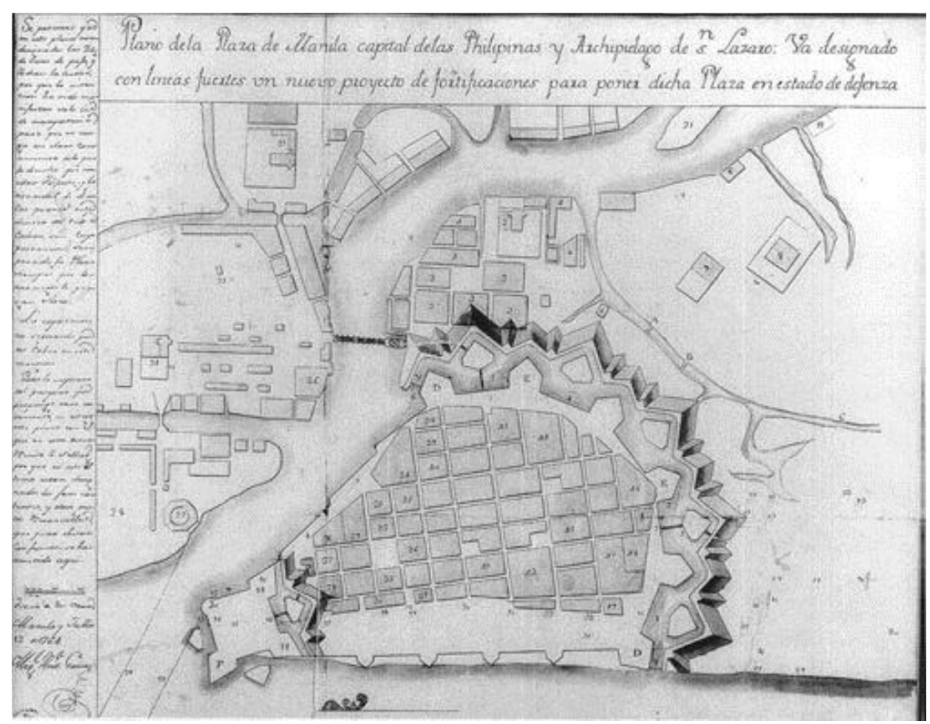

Figure 3: AGI, MP-Filipinas, 1764.

G. The Parian is abolished in 1860 and transferred to northern Binondo district. San Gabriel region is developed as a park. In 1818 Paco Park (a tomb) was built, and also a second Quezon bridge over the Passig River is built. The influences of the French Revolution in 1789 bring independence aspirations to the Spanish colonial cities. As a result of the Spanish-American war in 1898 The Philippines are transferred to the USA, and this episode ends the 333 years of Spanish rule over Manila since the first Spanish settlement in Cebú.

H. When the American rule over The Philippines begins, the US Defense Department determines that the walls bordering the Passig River should be completely demolished, and this task is accomplished in 1904. However, Intramuros is protected thanks to the architect Burham, who devised the urban plan for Manila. He put into value this walls as a defensive system from the Middle Ages, as well as the inner urban structure of Intramuros. Urban plan by Burham was not completed, as it comprised a very large territory. However, in Tondo and Binondo district the city block shape devised by Burham can be seen in the northern side of the Passig River.

By the Tydings-McDuffing Act of 1934, approved by the US Congress, The Philippines could become independence after a 10 years transition period. II World War broke up in 1941, bringing the Japanese forces to occupy The Philippines. Manila was occupied in January 2nd 1942, and raised a military government the next day. In response to the occupation of Japan, effective for 3 years and 8 months, the US forces would focus its military power on Manila to recover that territory; the consequences were catastrophic, and Manila was nearly completely destroyed until the end of the war in 1945. 


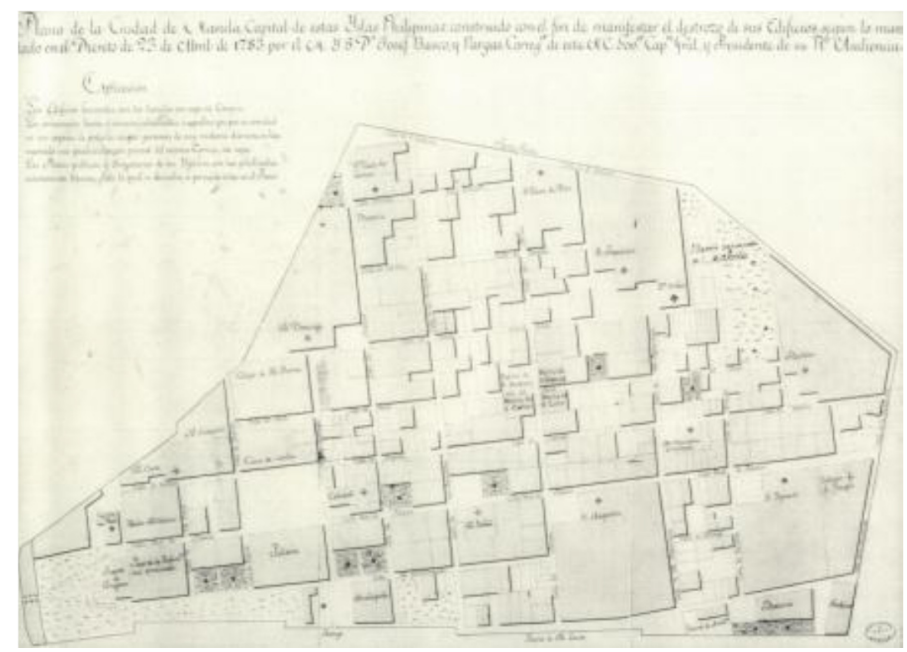

Figure 4: AGI, MP-Filipinas, 1783.

I. In 1951, President Elpidio Quirino called the attention over the need of restoration in Intramuros. The Intramuros Restoration Committee (IRC) is established in 1966, commanded by chairman Alejandro Roses; some of the walls, the 6 gates and Fort Santiago were repaired. In 1979 the Intramuros Administration (IA) is established under a government decree by President Marcos Ferdinand. Intramuros Administration has a mayor responsibility over the monitoring, repairing and conservation of Intramuros. Walls were reconstructed, except for the parts near the Passig River. This administration not only has an influence on Intramuros, but also over areas like Luzón, Ilocos, Vigán, Negros and others. This reconstruction process did not affect the city block configuration, so that the configuration that we can see today has not been altered significantly from the original.

\section{Spatial configuration of Intramuros}

\subsection{Distribution of buildings}

According to GIS data, Intramuros is composed of 54 city blocks, and 746 buildings currently remaining. 219 buildings con not be confirmed according to the field work, of which about 135 buildings are located in one single city block. The block are divide into portions where the different buildings are clustered, so it was not possible to assess the existence of every individual building inside each block. Given this situation, we considered a mixture between private housing and shops for these constructions. The small scale inside a city block indicated that residential and commercial uses coexist; despite the exact distribution cannot be specified, the general pattern can be recognised. 
Bahay na bato (meaning stone house) is a traditional dwelling construction that has been replaced in most cases. That on-site research has confirmed that about 329 of these structures have been replaced by RC buildings; 98 by wooden buildings; 25 by wooden and concrete buildings; 12 by stone buildings; only 11 by masonry buildings. Inside Intramuros we have surveyed only 144 dwelling houses, 144 dwellings that combines houses and shops, 113 buildings with commercial premises, 43 educational facilities, 36 buildings that hold garages, factories or warehouses, 27 buildings with government facilities, 21 buildings with public facilities, 16 religious facilities, 10 abandoned buildings, 4 buildings under construction could be confirmed. In relation with the building height: 137 buildings with one floor, 199 buildings with 3 floors and 106 buildings with 3 floors; the vast majority of constructions range from 1 to 3 floors.

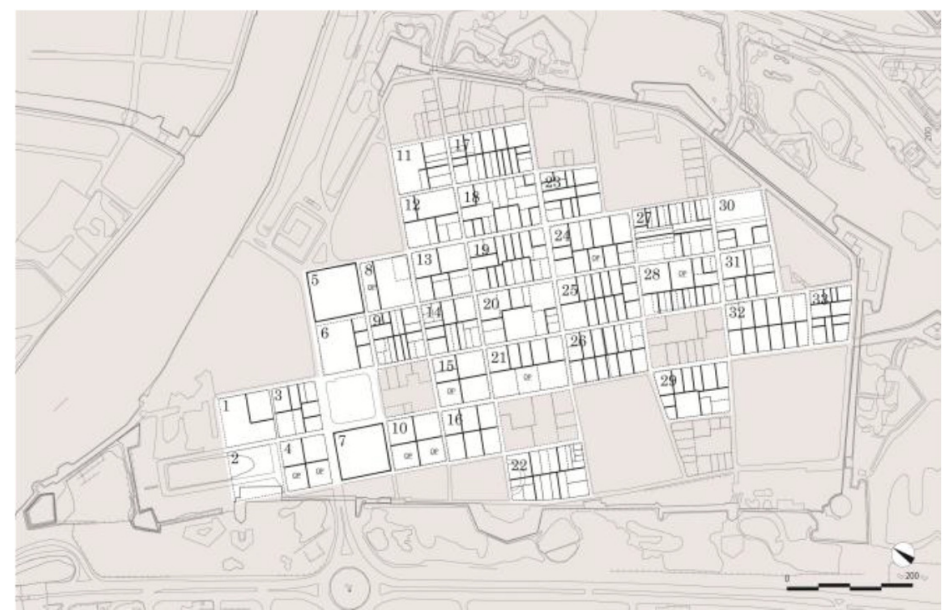

Figure 5: Spatial configuration of Intramuros District, 1783. (Own production.)

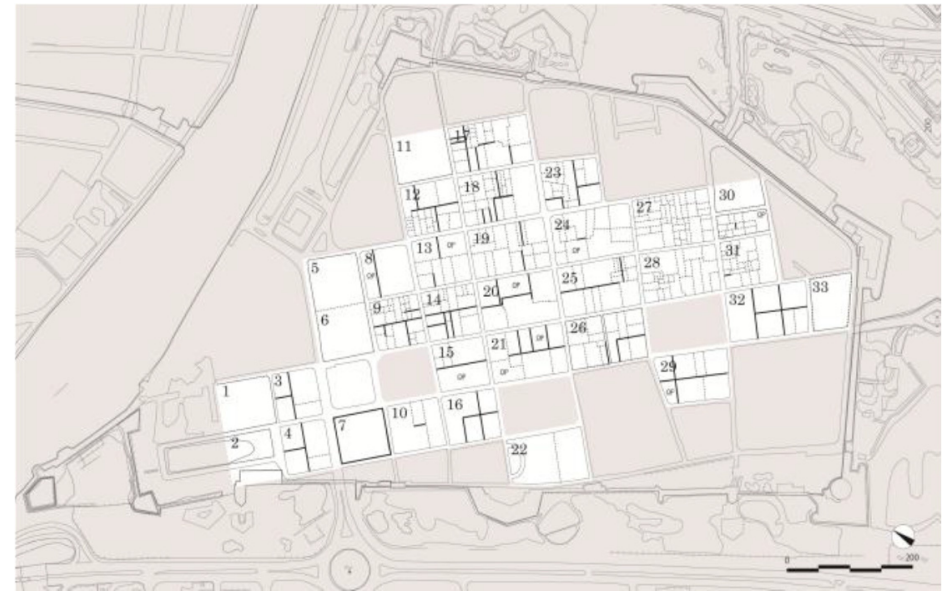

Figure 6: Spatial configuration of Intramuros District, 2012. (Own production.) 
At the beginning of the 20th century, until Second World War these were the main churches located inside Intramuros which remained unaltered from the original Spanish reign period: Manila Cathedral, San Agustín Church, San Francisco Church, San Ignacio Church, Santo Domingo Church, and Recoletos Church. Currently, only Manila Cathedral and San Agustín Church remain.

There are many educational facilities that have been built in the former places of religious facilities. Referring to the schools in Intramuros, there are several of them that remains from the Spanish period, like San Juan de Letrán University, which was moved to Quiapo suburb after the war, Santo Tomás University, Santa Rosa College and Manila High School. Apia institute of technology was built in the former location of San Francisco church, whose traces still remain; Manila City University, in San Francisco Church traces, and also other church related facilities, like Lacium University, in the location of San Juan de Dios; in Santo Domingo Church traces of the American Trade Bank can be found; in the Recoletos church location the publishing services for the US government was installed.

\subsection{Street system}

Measuring the street width in the intersections with the help of GIS systems, widths of $6.33-16.98$ vara $(1$ vara $=0.8359 \mathrm{~m})$ have been identified. Andrés Soriano Jr. Ave was widened in the American period. Measuring from the central point of the urban structure that is, the central square, and taking into account the eights roads departing from this central spot, widths of 6.33-12.56 vara have been measured; The average width in the East-West direction was 9.5852 vara, and in the North-South direction 8.91147 vara.

Intramuros is composed of two basic block types: rectangular city block and a south central square in downtown district. The difference can be seen basically in the North-South direction, there is no significant change in the East-West direction.

The scale in the East-West axis has been measured in 80.25-93.3 vara, with an average of 89.65 vara; this leads us to think that the city grid was planned with a basic measure of 90 vara.

The model of the Spanish colonial city consists on an orthogonal grid organised around a central square, and in this area the configuration is close to the original. But in the case of Manila, we can quote a view of the square before 1767 where a peripheral block is depicted, and also a design for a rectangular square in city views of 1771 and later. That means that the original urban structure had changed at least at the stage of 1771 . Street system of Intramuros is basically orthogonal, but focusing on the nucleus, an irregular grid can be found. We consider this changes to have taken place in the moment of reconstruction and repetition of building models.

Old Santo Domingo Church and near city blocks (Southeast of the square) has not change on the contrary. Scale on the North, South, East and West axis is 90x90 vara, and this is a consistent urban figure at least before 1767. That is, considering the original design of the city blocks, the module of $90 \times 90$ vara was used in the 
planification. City block configuration of Vigan is also 90x90 vara in all directions, the same as Manila.

On the other hand, the length in the North-South direction of rectangular dicy blocks is 138.21-156.04 vara, with an average of 146.93 vara. This means that the grid was probably planned with a North-South dimension of 90 vara and EastWest dimension of 150 vara, with the exception of Real Street, which was widened after the war.

\subsection{City block split}

According to AGI, MP-FILIPINAS, 1783 there is a view of the city depicting the land assigned in each block. As an overview to understand the shape of the plots (1715-1729) we can quote the picture of Rojas. There is no city view showing the initial percentage of residential construction, based on the illustration of Rojas; but we can compare front and depth for the residential area and their age according to three city views of 1783. It can be correlated with an urban area consisting of 33 blocks. This is summarised in the table showing the transition of residential plots in each city block.

Looking at the illustration by Rojas, we can see that the central square and the surrounding neighbourhood city blocks, in most cases, are divided into 2 or 4 parts. There are also many undivided block, whose structure is close to the percentage of residential land initial construction. There are various patterns to divide the city blocks in 12 or 14 parts in many cases. Basically, first, an East-West system divides the plot into Southwest-Northwest areas, and the North-South system performs the same operation, dividing the remaining plot into Northwest and Southeast parts. As mentioned before, the original city block pattern of 90x150 vara is split on 45 vara, remaining the plot depth, but the size of the plot is still the basic. This dividing line can still be noted in the plot configuration.

The city plot are further subdivided after 1783. Near the central square, corner blocks are divided following 2-4 patters, and rectangular blocks following 2-7 pattern overall. Many blocks located in Real Street, which connects Santa Lucía Gate and the Parian Gate, have been subdivided considering the commercial facilities aligned with the street. In order to promote gathering of people, party walls are built perpendicular to the street. The process of residential land subdivision from $1715 / 1720$ to 1783 changes the structure only a little. An initial plot of 35 is divided into 1 parts (19), 3 parts (11), 4 parts (4), 7 parts (1); initial plot of 16 is divided into 2 parts (15), 3 parts (1); there is a majority of blocks divided into 2 parts.

The patterns of residential land inside Intramuros that has been clarified has become a standard; in this sense, the damage of war is minor, looking at the current city block configuration. In spite of this, the residential uses have been reduced and fragmented. About 20-26 city block that comprises residential and small-scale housing is overcrowded, and in these cases the initial split of the block could not be determined. This process response to population growth and other factors. The number of subdivisions decreases after 1783 in blocks number 21, 23, 25 and 30. In block 30 there is a particular case, as in 1784 the Alcaicería de San José was built. 


\section{Conclusions}

Only 14 Spanish colonial cities were surrounded by walls, and in this group Manila is the 11th city. Santo Domingo in Española Island (1494) and Habana (1515) do not follow a grid pattern, but their urban structure is mainly orthogonal. In Panamá (1519), the prior case of Vera (1519) can be quoted, but after the "Edict of Phillip II on the World" of 1573 the colonial city urban plans are organised according to a system; in turn, Manila can be considered a representative model of an early 16th century Spanish colonial city.

These papers reveal the following advances additionally resumed:

1. The street system of Intramuros in Manila has not been altered significantly with the exception of the following. In the Spanish colonial period, the construction of the Parian Market that has changed the adjacent urban structure; the city blocks near Fort Santiago; in the United States colonial period, where the Passig River Walls were demolished and the adjacent blocks were also altered.

2. The urban area of the central square around the initial grid North, South, East and West is 100x100 vara each block; city blocks are 90x90 vara oriented following North, South, East and West directions. The street width is 10 vara between axes of the streets. This standard size is the same as in the World Heritage city Luzón. Central Square is planned on a basis of 100x100 vara, which is different from the provision of the act of Indias.

3. Other unique feature of Manila Intramuros is that an original city block is designed, which measures 90x150 vara, organised in North, South, East and West directions.

4. According to the construction period of the buildings, churches, monasteries, Town Halls and hospitals, we can assure that they were built around the city district of Intramuros and also around the central square. Considering combined housing and shops, they have been built around the rectangular city block centaur of Intramuros, in the Southeast side; the distribution remains unchanged today.

5. The depth of the residential plot has been divided in East and West directions in each city block. Dividing line of this depth is left as the boundary that can be seen nowadays. What is more, despite the great destruction of WW2, the current spatial configuration of Manila Intramuros corresponds to the initial spatial configuration dating from its Spanish colonial origins.

\section{References}

[1] Reed, R.R. Colonial Manila. The Context of Hispanic Urbanism and Process of Morphogenesis. University of California, 1978.

[2] Galván Guijo, J. Arquitectura y Urbanismo de origen español en el Pacífico Occidental. Universidad Politécnica de Madrid, 2004.

[3] Ortiz Armengol, P. Intramuros de Manila. De 1571 hasta su destrucción en 1945. Ediciones de Cultura Hispánica, Madrid, 1958.

[4] Torres, J. V. Z. Ciudad Murada: A Walk Through Historic Intramuros. Intramuros Administration and Vibal Publishing House, Philippines, 2005. 
[5] de Morga, A. Sucesos de las Islas Filipinas. Ed. Garnier hermanos, París, 1890.

[6] Bunag Gatbonton, E. Bastión de San Diego. Intramuros Administration Ministry of Human Settlements, 1984. 